\title{
The Branding and Promotion of Cultural Heritage. Case Study About the Development and Promotion of a Touristic Heritage Route in the Carpathian Basin
}

\author{
Assoc. prof. habil. Magor KÁDÁR, PhD \\ Department of Communication, PR and Advertising \\ Faculty of Political, Administrative and Communication Sciences \\ Babes-Bolyai University, Cluj Napoca, Romania \\ E-mail: kadar.magor@fspac.ro \\ Assist. prof. István BENEDEK, PhDc \\ Department of Communication, PR and Advertising \\ Faculty of Political, Administrative and Communication Sciences \\ Babes-Bolyai University, Cluj Napoca, Romania \\ E-mail: benedek.istvan@fspac.ro
}

\begin{abstract}
The study describes a comprehensive cultural branding plan, whose central form is Saint Ladislaus (St. László). The plan creates a Cultural Heritage Route of 44 settlements in Romania and Hungary having built heritage sites, legend-connected sites, natural values or settlement name associated with the saint. Based on a variety of background research and analysis the branding plan enlists the subjects and possibilities of cultural branding, defines brand elements, creates the segmentation and targeting of different target groups, makes a proposal for media and communication channels, elaborates a communication plan and formulates further suggestions. The study presents a plan for practical implementation, but at the same time aims to create a model for future branding and communication plans in cultural or place branding.
\end{abstract}

Keywords: Saint Ladislaus Heritage Route; Cultural branding; Heritage elements; Place branding; Touristic promotion. 


\section{Introduction}

The aim of the project is to create a Cultural Heritage Route (knight-king's road, King's Route) in the Carpathian Basin, basing it on the historical personality of Saint Ladislaus (Szent László). This route includes the built heritage sites, the legend-connected sites, natural values, and of course the settlements associated with St. Ladislaus. This way it is possible to introduce settlements and regions, making them more attractive for tourism, which by themselves only manage to attract few visitors. The project has multiple objectives:

1. it intends to build a thematic heritage route that draws attention to the central figures and elements of the cultural heritage and as such will have a community-forming effect, intending to strengthen common history and identity;

2. involving local communities, creating a comprehensive community project, which will become a point of attachment for its members, but can also become the basis of new elements and traditions related to the St. Ladislaus cult;

3. to document and record the present state of the built heritage, prospectively obtaining resources for preserving and restoring it;

4. to strengthen tourism and events, respectively services related to it in the heritage areas, offering new recreational, regional tourism or pilgrimage routes;

5. to operate services along the heritage path, which would create jobs and market local products.

The documenting, branding and communication task is rather complex, since the project is centered on a historical figure, while at the same time regional and touristic promotion, and even project promotion must take place as well; meanwhile, the different subjects communicated (historical figure, touristic services, settlement/region, project) must be complementary so that each one strengthens the others. This task is made easier by the fact that much of the diverse heritage related to St. Ladislaus remains to this day, be it built or intellectual. There is no need, therefore, to create new venues and sights, as is the case for less attractive regions; conversely, it is the abundance of elements that makes the task here daunting as the attractiveness of the route in question stems from its diverse heritage and many tourist attractions.

The proposed heritage route contains a total of 44 settlements where the presence of St. Ladislaus is obvious; 31 of these are located in Romania and 13 are located in Hungary. From the viewpoint of public administration, the Romanian settlements are spread out in eight counties: Bihor, Salaj, Cluj, Bistrița-Năsăud, Alba, Mureș, Harghita and Covasna. Every stop along the Romanian section of the route is therefore located in the historical regions of Transylvania and Partium. The selection of settlements was based on a prior analysis of the region, performed by a team of art history specialists. The team conceived a list of those settlements, which either contain built heritage, traditions, natural formations, or contain the 
name of the project's central character, the knight-king, in their current Romanian or Hungarian names.

Table 1. The settlements of the St. Ladislaus heritage route

\begin{tabular}{|c|c|c|}
\hline Settlement Name RO & Settlement Name HU & County \\
\hline Chiraleș & Kerlés & Bistriţa-Năsăud county \\
\hline Tileagd & Mezőtelegd & Bihor county \\
\hline Remetea & Magyarremete & Bihor county \\
\hline Oradea - the fortress & Nagyvárad - VÁR & Bihor county \\
\hline Oradea - the Roman Catholic cathedral & Nagyvárad - Székesegyház & Bihor county \\
\hline Băile 1 Mai & Püspökfürdö & Bihor county \\
\hline Sălacea & Szalacs & Bihor county \\
\hline Mugeni & Bögöz & Harghita county \\
\hline Armășeni & Csíkmenaság & Harghita county \\
\hline Mihăileni & Csíkszentmihály & Harghita county \\
\hline Crăciunel & Homoródkarácsonyfalva & Harghita county \\
\hline Vasileni & Homoródszentlászló & Harghita county \\
\hline Sânsimion & Csíkszentsimon & Harghita county \\
\hline Lunca de Sus & Gyimesfelsőlok & Harghita county \\
\hline Ocland & Oklánd & Harghita county \\
\hline Daia & Székelydálya & Harghita county \\
\hline Dârjiu & Székelyderzs & Harghita county \\
\hline Frumoasa & Csíkszépvíz & Harghita county \\
\hline Tureni & Tordatúr & Cluj county \\
\hline Fizeșu Gherlii & Ördöngösfüzes & Cluj county \\
\hline Mănăstireni & Gyerőmonostor & Cluj county \\
\hline Cheile Turzii & Tordai-hasadék & Cluj county \\
\hline Săvădisla & Tordaszentlászló & Cluj county \\
\hline Biborțeni & Bibarcfalva & Covasna county \\
\hline Ghelința & Gelence & Covasna county \\
\hline Chichiș & Kökös & Covasna county \\
\hline Saciova & Szacsva & Covasna county \\
\hline Pădureni & Sepsibesenyő & Covasna county \\
\hline Chilieni & Sepsikilyén & Covasna county \\
\hline Cricău & Boroskrakkó & Alba county \\
\hline Sânvăsii & Nyárádszentlászló & Mureş county \\
\hline \multirow[t]{13}{*}{ Uileacu Șimleului } & Somlyóújlak & Sălaj county \\
\hline & Baktalórántháza & Szabolcs-Szatmár-Bereg county \\
\hline & Kisvárda & Szabolcs-Szatmár-Bereg county \\
\hline & Laskod & Szabolcs-Szatmár-Bereg county \\
\hline & Napkor & Szabolcs-Szatmár-Bereg county \\
\hline & Szabolcs & Szabolcs-Szatmár-Bereg county \\
\hline & Ócsa & Pest county \\
\hline & Somogyvár & Somogy county \\
\hline & Tereske & Nógrád county \\
\hline & Tornaszentandrás & Borsod-Abaúj-Zemplén county \\
\hline & Vizsoly & Borsod-Abaúj-Zemplén county \\
\hline & Velemér & Vas county \\
\hline & Türje & Zala county \\
\hline
\end{tabular}


These are the main settlements mapped by the project using various methods of research and analysis, with the results posted online later on, included in a touristic project, thus creating the possibility to visit and take conscious/informed local and cultural historical trips.

\section{Data collection and research}

The place branding activity usually starts with the situational analysis of the specific settlement or region. It is worthwhile to perform both the primary and secondary research during the assessment (position paper writing) stage. In terms of primary research, the most frequently used ones are questionnaires filled out by the internal and external target audience, in-depth interviews with the key members of the region and settlement as well as quantitative data collection using surveys among the local population. Secondary research mainly involves content analysis, whether it is about analyzing documents, websites or media appearances. Content analysis is a frequently used research method in communication sciences and we can distinguish two major types. The quantitative content analysis examines the frequency of appearances while qualitative analysis deals with their interpretation. Content analysis methods include analysis of monographic descriptions of the settlement, current development plans, analysis of previous offline and online materials, and analysis of the media and online image of the settlement. These situational analysis methods can be effectively applied not only to one settlement but also to whole regions (Kádár 2014). For the more effective promotion of the St. Ladislaus Heritage Route it is subservient to take a look at those natural and cultural values that are that also tourist attractions, that can be highlighted to the target audience, can be included as buzzwords in messages during communication, thus the project uses both primary and secondary situational analysis in order to determine the touristic potential of certain settlements.

During the content gathering and analysis phase of the project (January to July, 2017), several preliminary tests were performed, each contributing to the discovery, documentation and archiving, using the author's own methodology (Kádár 2017).

1. Descriptions from art history. When accounting the settlements, there were identified 44 Romanian and Hungarian settlements that have a built heritage, legends or traditions, natural sights, or by the way of their name are preserving the name of the project's central figure. The specialist art historian group, formed by archaeologists, mural experts, settlement historians and natural science experts uncovering natural riches, prepared a detailed and documented description for each of the 44 settlements on the list, focusing on the connection between the individual settlements and their connection to the St. Ladislaus cult. The method used was the monographic data collection and analysis, 
resulting in each case in a summary prepared with catalog-like details. These materials are suitable for a more detailed presentation for the heritage-path, as well as they were the base for preparing the tri-lingual excerpts in Hungarian, Romanian and English, the descriptional segments used in the touristic promotional materials, the content segment of the website as well as the informational panels placed along the path.

2. Analysis of the media-presence of settlements. From the perspective of the success of the project, it is key to analyse how the settlements found on the path are communicating, in what way they place themselves and what values they express during their elaborate or spontaneous marketing communications. There was a separate online media analysis for the Transylvanian settlements (Benedek 2017b), taking into account portals with most views also having an online archive. The time periods analysed were based on the territorial coverage of the news portals: portals of local interest had a time period of one year (January 2016 - January 2017), while regional and national news portals a period of two years (January 2015 - January 2017). The keyword search consisted of searches for the settlement's name, as well occurrences for the settlement's name in conjunction with St. Ladislaus.

3. Online presence and visual representation. A keyword search engine analysis was performed with the help of Google search engine - website used for $89 \%$ of searches worldwide (Statista, 2017) -, searching for the settlement's names and their link to St. Ladislaus. The analysis contains the first page of search results, knowing that only less than $10 \%$ of users click on second page results, and $91 \%$ of users take into consideration only results that appear on the first page, according to research performed amongst internet users (van Deursen - van Dijk 2009). The online visual representation analysis researched the image search results separately. The method is similar in this case as well, using Google search engine it was possible to perform a keyword search for each settlement. The first 10 image results were analyzed based on the following criteria: theme, chromatics, format, resolution, relevance, reference to St. Ladislaus (Benedek 2017b).

4. Structured interviews. Compared to online and media analysis, which are secondary, the local interviews can be considered primary data recordings. Experience shows that during settlement and region analysis local interviews that prove most effective are mixed type, mixing structured and in-depth interview strategies (Kádár 2016). The essence of this method is that during the beginning of the conversation, the researcher asks questions, and gradually leaves more opportunity for the subject to express their opinion. The pre-defined questions consequently should be viewed as guidelines. At the same time, a mixed interview provides the opportunity to expand on certain subjects, issues and helps with their better understanding. The interviewer also conforms to this, phrasing 
the essential topics for analysis, however does not record them either word for word, or in chronological order. Three separate topics were distinguished: the general situation of the settlements, the evaluation of the touristic potential of the settlement and the link between the settlement and St. Ladislaus, meaning how the figure and legends of the knight-king relate to the settlement.

From the branding and place analysis point of view talking to people that have considerable knowledge about local values, are active in the community, are opinion-forming is a priority, preferably taking the form of a semi-structured or in-depth interview. Their views and information they provide add to forming a larger picture, on many occasions leading to opening more data collection and documentation processes. The selection of interview subjects was performed together with the organization responsible for the project, each settlement or smaller region was represented by one person. Based on the organization responsible for the project, local administrative representatives and the media image this person count as one helping form public opinion, as well as is knowledgeable about the settlement, about heritage elements linked to the St. Ladislaus cult, regardless whether in the community they are in a position of power or not. A total of 25 interviews took place in the counties Bihor, Harghita, Covasna and Cluj (Benedek, 2017a) on the basis of which the settlements were categorized into groups based on touristic charm and infrastructure, and links to the St. Ladislaus cult.

5. Visual documentation of heritage elements. To present and archive the touristic potential, summing up the results of the previous three data collection and research processes was the starting point, which was augmented by a visit to the locations to verify the validity of the data as well as their large scale visual documentation. There was a short film and a time-lapse video from a drone prepared about each of the settlements, and the heritage elements posing the subject of the project (murals, buildings, natural sights) were documented by high resolution image series. The visual documentation served a double purpose: firstly, to document the current state of the heritage elements, secondly to provide visual materials for the tourist promotions. The collected visual materials can be attained on the project's website, as well as appear on the panels and promotional materials.

The sights, heritage elements were present in art historical descriptions, these were augmented by the analysis of sights mentioned during the mixed interviews, media analysis, and analysis of publications and tourist informational materials. Thus the data collection processes are interlinked, one strengthening the other, and the priming, exploratory research was checked by fieldwork, interviews and visual documentation. While presenting the research results, alongside the opinions of the interviewees, the opinion of the group of experts participating in the 
project, and the content of the given settlements' tourist communications was also a factor. The analysis of the tourist communications from a settlement consisted of the evaluation of the attainable printed or online informational content relating to the given settlement.

The collected materials, like the art historical descriptions, short, multilingual excerpts, visual elements and tourist attractions and tourist plan can be found on the website that stands at the basis of the project (www.kingsroute.org), all are free to access and with the possibility to provide feedback and additions to the site. There is an important role in future for those who concern themselves with the heritage of St. Ladislaus, or the history, sights, traditions of settlements found on the route, so that with their contribution the database can be broadened and become more detailed.

\section{The subjects of promotion}

As previously stated in the project description, the aim of the project is to establish a heritage route that connects those Romanian and Transylvanian settlements (in the project's later cycles all settlements) that are in some way connected to St. Ladislaus. To this day, the king's cultural heritage is very much alive among the members of Hungarian society; his memory, however, extends to the region's other nations, on the catholic community as well, and has, in a wider sense, a European dimension to it, as he is one of the well-known figures of European history. Although his presence is more strongly felt on his kingdom's territory, his image can be seen on the frescos of several European churches, and historical references to St. Ladislaus are spread out beyond Europe to this day. Numerous built heritage, natural formations, legends and settlement names point to the fact that St. Ladislaus remains an important element in the culture and identity of the region, thus warranting a project that promotes his life, deeds and heritage. Establishing and showing a comprehensive view of his values on the one hand strengthens a regional sense of belonging and a cultural-national identity, and on the other hand serves to inform both those who are familiar with the traditions related to St. Ladislaus, as well as those who are hearing about him and his deeds for the first time. The primary subject is therefore the person of St. Ladislaus and the cultural elements tied to him. A cult of personality already shows that it is in fact the method of personal branding often used with public figures that is the most apt for the project.

There are several settlements along the heritage route which do not have sufficient appeal on their own; one of the primary goals of the project is to link these settlements together, allowing them to jointly draw in tourists, reaching out to new target groups who previously would not have visited the aforementioned settlements indeed, the region itself. The heritage route also has the potential to develop 
the economy of the settlements, by creating new services and new workplaces. The secondary subjects of the branding activity are therefore the settlements and regions that are connected to St. Ladislaus, be it through man-made heritage, legends or natural formations.

The third object of promotion is the project's website, which facilitates the conveying of the project to the target groups, complemented by social media sites and the app. It gathers information related to the settlements along the heritage route, reveals the ways in which they are connected to the king's person, while presenting the settlements through descriptions and audiovisual material created by specialists. The website will be the starting point for planning trips and routes as well, as it will provide suggested routes and interactive route-planning, it will facilitate the booking of accommodation, as well as mark touristic attractions and places of interest. The website creates the bridge between the target group and the elements that constitute the content of the project, it distinguishes the project, by being the first interface that makes its visual identity discernable.

To sum up, the branding and popularization cover several subjects with different characteristics. The synergies between the three subjects' branding and promotion can result in the image that makes the project recognizable, attractive and lovable.

Their features can be summarized as follows:

Table 2. Branding subjects connected to the St. Ladislaus heritage route

\begin{tabular}{|c|c|c|c|}
\hline & $\begin{array}{l}\text { The person } \\
\text { of king St. Ladislaus }\end{array}$ & Landmarks, settlements & Central project website \\
\hline Type of branding & $\begin{array}{l}\text { personal branding, } \\
\text { idea and ideology branding }\end{array}$ & place branding & $\begin{array}{l}\text { organisational } \\
\text { or service branding }\end{array}$ \\
\hline $\begin{array}{l}\text { Historical character } \\
\text { of the image }\end{array}$ & $\begin{array}{l}\text { long term, spontaneously } \\
\text { developed }\end{array}$ & $\begin{array}{l}\text { long term, spontaneously } \\
\text { developed or unknown }\end{array}$ & short term, planned \\
\hline $\begin{array}{l}\text { Localisation } \\
\text { of the image }\end{array}$ & known in Hungarian culture & $\begin{array}{l}\text { known in local } \\
\text { and regional context }\end{array}$ & unknown \\
\hline $\begin{array}{l}\text { Uniformity } \\
\text { of the image }\end{array}$ & monolithic, institutionalized & fragmented, locally known & monolithic, new initiative \\
\hline
\end{tabular}

\section{Target Audience Segmentation and Targeting}

The essence of the target audience segmentation is to define groups that have uniform attributes and which can be addressed, can be reached, assuming that members will respond in similar ways to messages. The demographic segmentation is clear, where ethnicity, regional location and marital status are obvious criteria but in reality they mostly help to better understand consumption habits of customers: a family with children has different traveling habits than a group of elderly people or a young couple; furthermore, the cultural embeddedness, generational affiliations or interests will determine the required services to be con- 
sumed. This is why the segmentation start with touristic habits, complemented by other behavioral patterns, and to lesser extent by demographic segmentations. Dissections based on consumption patterns take into account on one hand the reasons for consumption setting up groups (for example culture-consumption based on stylistic preference), and mapping the rationale of non-consumers on the other hand in order to prevent any pitfalls, and to have the possibility to address them later (such as financial resources, dependence on other groups, causes for the lack of interest, etc.).

The communication process begins with the clarification of goals, followed by setting up target groups, elaborating a message for each, and sending these messages through the appropriate channels (targeting), thus triggering a shift in awareness, beliefs, attitudes and behaviors (Kádár 2008, p.13-14). In many cases the messages are first created, then formulated and edited to suit the specific channels of communication (copywriting). It is often the case, however, that during the partitioning of the target group, the use of different media and communication channels may already be considered group characteristics by which the group may be described (e.g. the online-activity of the Z-generation). The wording of the messages may therefore be suited according to the channel where they are to be displayed.

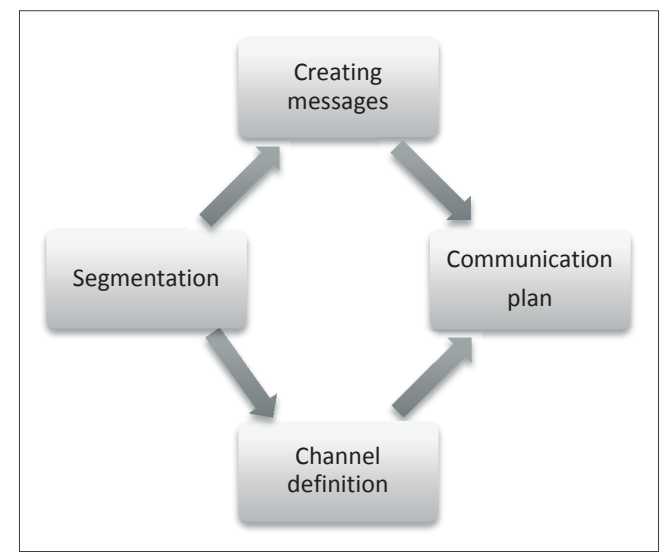

Figure 1. The communication planning process

The target group segmentation of the Saint Ladislaus Heritage Route is planned using consumption habits and demographic characteristics, focusing on complex cross breaks. Regarding brand strength, the aspects of examination will include the degree of familiarity with the subject, affinity or attachment to it, and the positive or negative feelings towards it. 


\section{Touristic target-group segmentation}

The evaluation of the positioning and communication activities of settlements is the domain of place-branding. Due to the complex nature of its activities, the target group of place-branding is rather wide. At least four large groups are discernible: visitors, residents, business and industry, as well as export markets. The branding or promoting activities that target tourists are gathered under the term "destination branding". The end-goal of place branding is the same, regardless of the target group. The definition of destination branding points to this as well, as the goal of the activity is simply to communicate the unique identity of the destination, through which the given settlement can distinguish itself more efficiently from the its competitors. Specialist literature often uses these two terms interchangeably, and this is understandable, as the destination never moves away from the place where it is geographically located.

The partitioning of the touristic target-group was achieved through cross-segmentation, taking into consideration at least three demographic factors, consumer habits, knowledge and experience levels or attitudes. Knowledge of the knightking's cult, cultural proximity and regional proximity constitute the first partitioning criterion, followed by travelling, visiting patterns, in other words, partitioning by tourist-behavior. The subchapter of touristic target-group segmentation contains the characteristics of each group in part, based on which messages and touristic offers can be formulated. The communication plan also contains the ways in which these groups may be reached, the channels that should be used. This information should be sufficient to plan ways in which to communicate the routes of different regions, or even the entire heritage route. The cross-segmentation of the target-group based on proximity, attachment to the knight-king, as well as touristic behaviour can be seen below.

The description of the target-groups is complemented by the unique behavior of the different groups, which in turn influences they mobilize when visiting, as well as their participation in programs. Besides the partitioned groups, it is worthwhile mentioning one more important segment, which sometimes may even be viewed as the base group: although they are only occasional visitors and often takes part in impulsive, go-with-the-flow trips and visits, it is nevertheless important to keep in mind that they are from the region, the know the places, and they are tied to either the settlement's or the region's heritage.

\section{1. category: organized groups (Groups $1,4,7$.)}

- organized by an institution (school, agency, party, religious groups), is typically a community;

- the religious nature of it can be highlighted, a St. Ladislaus pilgrimage prestige-visit aspect can be formed ("I've already been to ..."). 


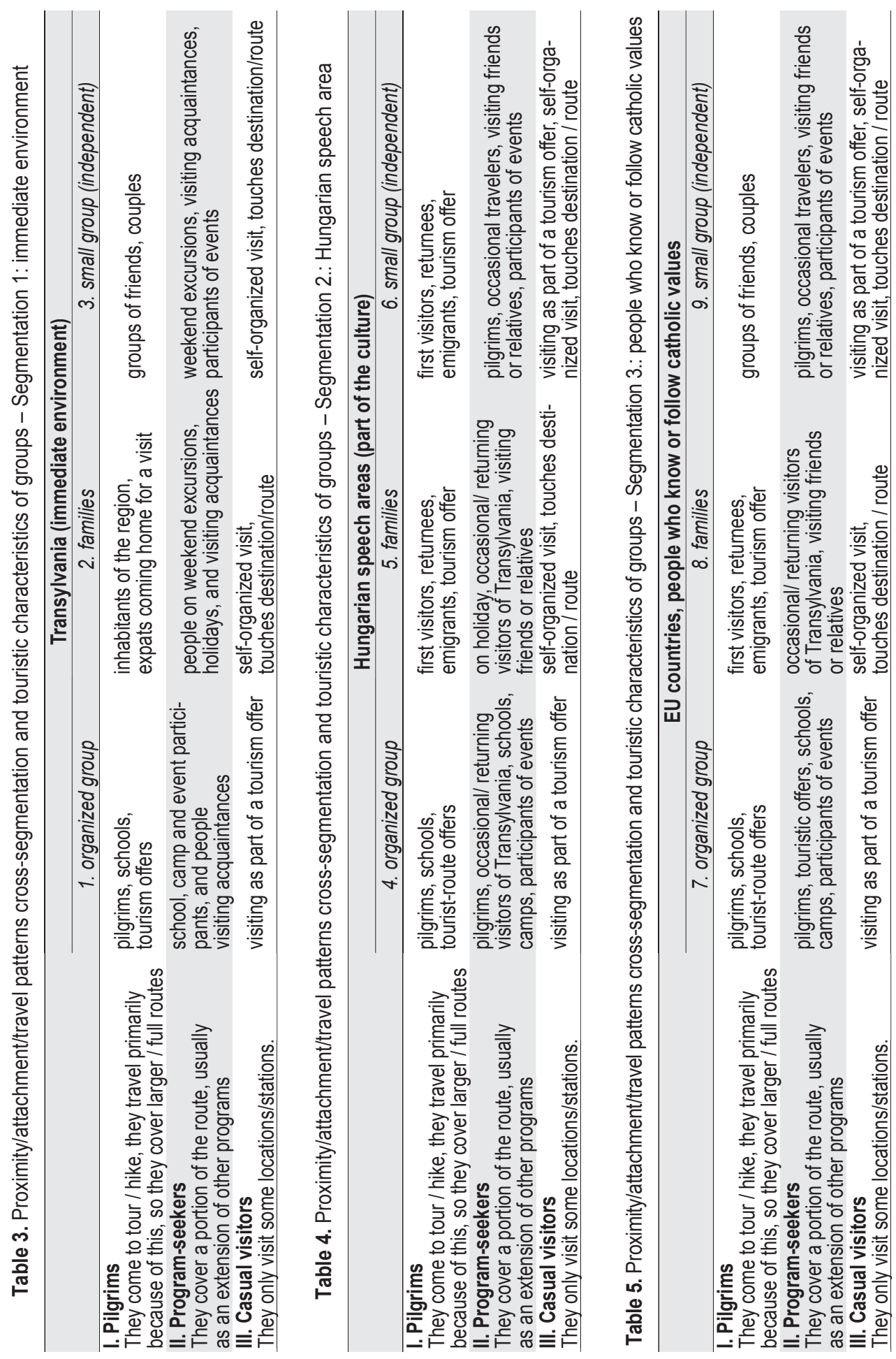




\section{2. category: families (Groups 2, 5, 8.)}

- traveling with children, typically in the 4-5 family life cycle stages (young couple with children - older couple with children);

- can be first visitors (looking for connection and security), returning visitors (previously formed relationships, and program / accommodation preferences) and home-coming emigrants (family / friends, strong attachment, visits with an educational purpose).

\section{3. category: small, independent groups (Groups 3, 6, 9.)}

- loose structure, couples or individual travelers banded together, without children, youthful, internet-using generation;

- self-sufficient, they organize their programs themselves;

- they are looking for relaxation, they combine it with other programs.

\section{4. category: visitors from non-Hungarian speaking regions (Groups 7, 8, 9.)}

- primarily cultural or religious visits, treating Transylvania as a destination;

- they are looking for complete programs, including travel, accommodation and alternative activities;

- languages of communication: Romanian, Hungarian, English and German.

\section{5. category: occasional visitors}

- responds to the call to action to visit places in the neighborhood;

- typically a short visit, which is a subject or part of a weekend trip;

- linked to other visits, e.g. visits to friends or relatives, pilgrimage, other activities in the area (e.g. treatment).

Finally, the transport affinity of the aforementioned segmentation of groups can also be prepared, which helps planning, and designing the route, but it also determines the use of promotional channels (e.g. website, phone applications, brochures). The same categorization can also be used for phrasing the values and messages.

Table 6. Transport habits of target groups, values on which messages are based -

1. Segmentation: immediate environment

\begin{tabular}{|c|c|c|c|}
\hline & \multicolumn{3}{|c|}{ Transylvania (immediate environment) } \\
\hline & 1. organized group & 2. families & $\begin{array}{l}\text { 3. small group } \\
\text { (independent) }\end{array}$ \\
\hline Typical means of travel & bus, train & car, bus & car, hitchhiking, bike \\
\hline $\begin{array}{l}\text { Values } \\
\text { upon which messages } \\
\text { can be based }\end{array}$ & $\begin{array}{l}\text { local value, } \\
\text { Hungarian cultural heritage }\end{array}$ & $\begin{array}{l}\text { trip, local value, } \\
\text { Hungarian cultural heritage }\end{array}$ & $\begin{array}{l}\text { recreational trip, } \\
\text { scenery, local value }\end{array}$ \\
\hline
\end{tabular}


Table 7. Transport habits of target groups, values on which messages are based 2. Segmentation: Hungarian speech area

\begin{tabular}{|c|c|c|c|}
\hline & \multicolumn{3}{|c|}{ Hungarian speech areas (part of the culture) } \\
\hline & 4. organized group & 5. families & $\begin{array}{l}\text { 6. small group } \\
\text { (independent) }\end{array}$ \\
\hline Typical means of travel & bus, train, plane & car, bus & car, bus, train, plane \\
\hline $\begin{array}{l}\text { Values } \\
\text { upon which messages } \\
\text { can be based }\end{array}$ & $\begin{array}{l}\text { trip, emotional attachment, } \\
\text { Hungarian cultural heritage }\end{array}$ & $\begin{array}{l}\text { trip, emotional attachment, } \\
\text { Hungarian cultural heritage }\end{array}$ & $\begin{array}{l}\text { trip, } \\
\text { Hungarian cultural heritage }\end{array}$ \\
\hline
\end{tabular}

Table 8. Transport habits of target groups, values on which messages are based. Segmentation 3. people who know or follow catholic values

\begin{tabular}{|c|c|c|c|}
\hline & \multicolumn{3}{|c|}{ EU countries, people who value the catholic culture } \\
\hline & 7. organized group & 8. families & $\begin{array}{l}\text { 9. small group } \\
\text { (independent) }\end{array}$ \\
\hline Typical means of travel & bus, train, plane & bus, train, plane & bus, train, plane \\
\hline $\begin{array}{l}\text { Values } \\
\text { upon which messages } \\
\text { can be based }\end{array}$ & $\begin{array}{l}\text { cultural curiosity, } \\
\text { touristic trail, religion }\end{array}$ & $\begin{array}{l}\text { cultural curiosity, } \\
\text { touristic trail, religion }\end{array}$ & $\begin{array}{l}\text { city break combo, individual } \\
\text { trail, cultural curiosity/ interest }\end{array}$ \\
\hline
\end{tabular}

\section{Targeting the target audience}

The role of targeting, meaning message targeting, is to reach and address predefined target groups in a way that elicits a positive response. This can be informing, when the target group's knowledge is richened with information about a specific subject, place, service; can be attitude-shaping, which manifests in a positive reaction, desire to travel; can be a call to action, which in this case means the participation at the journey, making travel plans; or it can be fastening, when the established habits persist for a longer time, the person becomes a return visitor as well as a reference person for the program, who based on experiences will recommend it to others (2008, p. 13-14).

The process of targeting requires prioritizing the target audiences, which in most cases is based on attachment or affinity, the groups that are frequent and have a prominently positive attitude become the primary or base groups. From an economic standpoint, it is possible to prioritize based on visits and consumption, who are the people going back most often or are most profitable to the tourism industry and related services. From the point of view of the image, groups that will present the project to a wider audience, ensuring its international representation, or have a multiplier effect (opinion leaders, media representatives, social media hubs) can become a base group.

Due to the above, the project's target audience segmentation has a complex cross-segmentation, which primarily can be used in the project's tourism aspect, 
however it is possible to perform segmentations from alternative points of view, and to create other target groups. Segmentation is possible, for example based on the segmentation used for the knight-king's personal cult, groups of Romania outside of Transylvania or foreign visitors, school children now getting acquainted with the knight-king, etc. can be included. The scope of the project is to provide an information background for all of this, and work as an open source, providing the opportunity for new contrivers to create, engage and involve groups based on their own perspectives, thus ensuring the survival of the intellectual heritage.

A separate message sequence can be created for each of the segment groups, while the general messages used in the informational and presentation materials about the project are taken from the project's goals. These form the message axes (message box):

1. Vivification of the St. Ladislaus cult: the heritage route will guide attention to the person of the knight-king and its heritage elements, thus having a community shaping effect, meant to strengthen the region's common history and identity.

2. The community project aimed at the community: a comprehensive project which by presenting the local values and communities provides the link to a larger program.

3. Documents, presents and preserves values: it aims to document and record the current state of the man-made heritage, prospectively even obtain resources for preservation and repairs. This is aided by the scientific descriptions and the visual documentation, all being up to date.

4. All was prepared by long and thorough specialist work: when selecting the settlements that are part of the projects, their connection to St. Ladislaus needed to be evident, after this a multi-faceted art historian specialist group documented, gathered and processed the data. On the website short excerpts as well as longer, scientific documents will be attainable

5. Tourism and commercial growth effect: it provides an opportunity for more isolated settlements to become a part of the tourism sector, they will be able to evolve and commercialize linked services.

6. Open to development, expansion: anyone can join, supplement the existing information or recommend additional settlements and routes.

\section{Communication guidelines}

As already set in the chapter dealing with the subjects of the branding, the central element of the project is St. Ladislaus and his cult, those settlements which are linked to his person by architectural heritage, legends, natural values or place names, as well as the website describing and documenting his person and the settlements (www.kingsroute.org). The promoting follows a reverse train of 
thoughts and focuses the attention on the website containing the information, descriptions and related services gathered during the phase of data collection, presenting the settlements and the cult of St. Ladislaus based on these issues.

The structure of the website, the display of the information and the visual features are transparent, coherent and easy to search. Their aim is to offer quick information, easily available via cellphone and suitable for a later app. The description of the program, the life of St. Ladislaus, the description and visual presentation of the related settlements, touristic routes, additional information and contact details are all situated at a single step from each other. According to the target group requirements, the same information is displayed in three languages, Hungarian, Romanian and English, route planning is supported by Google Maps while the accommodation section is linked with the online booking system of the Travelminit travel agency, a partner of the project. Online communication is completed by the Facebook account of the project (https://www.facebook.com/SzentLaszloUt) featuring information about the website, the settlements mentioned on its first page and the events, reflections and comments related to the project. The online surface addresses especially the members of the $\mathrm{Y}$ and $\mathrm{Z}$ generation and offers access for the growing new generation too. The more senior generations are reached by the information indirectly, through media publications, and the planning of the route is done together with other people or with the help of travel agencies.

The website and the page displayed within the social media are the primary carriers of visual identity. The project has its own element of visual identification, an abstract, simplified, golden brown image of the well-known picture featuring the knight-king. In publications, leaflets and on touristic information boards this is replenished by green and pastel colours and a triangular frame.

Therefore, the promotion starts with new, touchable elements (website, elements of visual identification) and uses the methods applied in organizational and service branding. This is the starting point of settlement branding which is completed by events and tour routes, and implies local communities. The third level is represented by the cult of St. Ladislaus, where the well-known central personality of the king is displayed though the methods and tools of personal branding, strengthening its role in the shaping of a national identity.

\section{Promotion plan: instruments and channels}

The promotion plan may be divided into two phases, each of them having their own intensity and info distribution (Kádár 2008, p.130-133):

\section{The launching phase, started with a teaser:}

The period between the $15^{\text {th }}$ of January 2017 and the $18^{\text {th }}$ of October 2017.

\section{The continuous sustenance phase:}

The period between the $18^{\text {th }}$ of October 2017 and the $15^{\text {th }}$ of July 2018 . 
The end of the second phase has a strong, increasing peak which is suitable for the launching of summer programs and, on the other hand, it is also suitable to introduce a possible enlargement or completion of the project.

The first section aims to describe the project and the website through the targeted channels, without the need for premium advertising. The project was launched in January 2017, it took a period of six months to collect and process the data, prepare the website and the presentation material, followed by a teasing or lead-in period (beginning of July 2017 - mid August 2017). The primary tools include the presence at different events, media coverage, the launch of the social media site and the media presentation and introduction of the homepage at various events.

Table 9. Appearance at thematic or target-audience-specific events during the teasing period

\begin{tabular}{|c|c|c|}
\hline Date & Event & Promotion role \\
\hline $\begin{array}{l}\text { January } 25, \\
2017\end{array}$ & $\begin{array}{l}\text { Cluj Napoca, project launching } \\
\text { press conference }\end{array}$ & $\begin{array}{l}\text { The first announcement of the project, the winning of the grant, } \\
\text { the programs of the St. Ladislaus Year }\end{array}$ \\
\hline $\begin{array}{l}\text { May 15, } \\
2017\end{array}$ & $\begin{array}{l}\text { XXVI. Festum Varadinum, } \\
\text { Oradea }\end{array}$ & $\begin{array}{l}\text { First presentation of the project in the presence of the target } \\
\text { group's nucleus (people from Nagyvárad, Hungarians, Catholics) }\end{array}$ \\
\hline $\begin{array}{l}\text { October 18, } \\
2017\end{array}$ & Kisvárda Days & $\begin{array}{l}\text { Launching of the project in Hungary, website launch, target envi- } \\
\text { ronment, high media coverage. }\end{array}$ \\
\hline $\begin{array}{l}\text { October 23, } \\
2017\end{array}$ & $\begin{array}{l}\text { Oradea, project launching } \\
\text { press conference }\end{array}$ & $\begin{array}{l}\text { Launching of the project in Transylvania, website launch in the } \\
\text { presence of the target group's nucleus, target environment, high } \\
\text { media coverage. }\end{array}$ \\
\hline
\end{tabular}

Each project presentation was followed by media coverage reaching other, broader target groups (Hungarians from Transylvania and Hungary). To achieve this, the launching (Festum Varadinum, Oradea) and the locations (e.g. the church of Ghelința with its painted walls) were chosen to be appealing to the media and at events where the presence of the target group and the level of mediatisation are both high. The media coverage of the project is supported by a well-known program coordinator of the St. Ladislaus Year, a representative character of the project (co-branding) who is present at each event and acts as a bond for project identification and the building of a uniform image. However attractive it may seem, the project itself does not intend to create its own independent events. Instead it wishes to reach its target groups directly by being attached to other events, and indirectly through the media, emphasizing the values of St. Ladislaus, the involvement of the community and the availability and proximity of the project. At the events where the project is presented we focus on general messages, the message box elements, the presentation of the workflow and results, the involvement and mobilization of the audience.

The social media page of the project is launched in parallel with the opening press conference ( $25^{\text {th }}$ of January), the elements of visual identity are displayed during the teasing period ( $1^{\text {st }}$ of June). With the launch of the website $\left(17^{\text {th }}\right.$ of $\mathrm{Au}$ - 
gust) the elements of visual identification and the periodic impulses sent to the social media are turned into a platform by the end of the second promotion phase. Thus the first phase promotes through personal and host events, media reports and social media.

Table 10. Romanian-Hungarian online media products, broken down by coverage

\begin{tabular}{lll}
\hline \multicolumn{1}{c}{ Coverage } & Online media products & \multicolumn{1}{c}{ Website } \\
\hline countrywide & Transindex & www.transindex.ro \\
\hline countrywide & Maszol & www.maszol.ro \\
regional & Krónika Online & www.kronika.ro \\
regional & Székelyhon & www.szekelyhon.ro \\
\hline regional & Nyugati Jelen & www.nyugatijelen.com \\
\hline Mureș county & Marosvásárhelyi Info & www.marosvasarhelyi.info \\
\hline Mureș county & Népújság Online & www.e-nepujsag.ro \\
\hline Harghita county & Udvarhelyi Hírportál & www.uh.ro \\
\hline Cluj county & Szabadság & www.szabadsag.ro \\
\hline Covasna county & Háromszék & www.3szek.ro \\
\hline Covasna county & Székely Hírmondó & www.hirmondo.ro \\
\hline Bihor county & Erdély Online & www.erdon.ro \\
\hline Satu Mare county & Szatmár.ro & www.szatmar.ro \\
\hline Satu Mare county & Friss Újság & www.frissujsag.ro \\
\hline
\end{tabular}

The second phase of promotion begins with the introduction and launch of the website. Beside the presentation of the program we may find descriptions of the settlements and visiting routes, which may be drawn through the partner companies and through the website design module. Beside the second promotional element a multilingual communication is displayed according to the content of the target group. The personal online communication channels are still used as instruments (website, social media) but they are also completed by new channels: travel agents and portals, travel blogs (in Hungarian, Romanian and English), the online and offline channels of media partnerships and partner projects. The information of the target group is broadened by information publications and touristic info boards placed on the spot.

During the sustenance phase the content of the personal social media page will feature the following elements:

-the phases of the project, updates, novelties, new partnerships;

-the settlements mentioned on the webpage, emphasized one by one;

- promotion of personal events and the events organized by these settlements;

- participation at events;

- media coverage, media releases;

-tours, announcements and tours made by the partner organizations; 
-the coverage of tours, travel articles and visitors' feedback;

-featuring new places of interest, special programs, accommodation;

- games and competitions;

- other content related to St. Ladislaus;

- other, topic-related activities in Transylvania and Hungary;

- project reports, achievement, the launch or conclusion of the next phase.

According to the break-up of the tourist target group, the Romanian speaking, primarily Transylvanian target group is reached via travel agencies and well-known Romanian travel bloggers who have already written about Hungarian cultural projects (Covasnamedia 2017; Weradio 2017). The list of Romanian travel bloggers was put together based on a touristic promotion done in 2016 and 2017 by county councils, in which they asked Romanian bloggers and celebrities to travel to the region and write about their experience.

Table 11. Romanian and Hungarian travel blogs

\begin{tabular}{|c|c|c|}
\hline Country & Travel Blog & Website \\
\hline \multirow{7}{*}{ RO } & TukTuk & www.tuktuk.ro \\
\hline & Valiza cu Călătorii & www.valizacucalatorii.ro \\
\hline & Drum liber - Vezi România cu alți ochi & www.drumliber.ro \\
\hline & ExTraViTa - Experiențe, Visuri, Călătorii & www.extravita.ro \\
\hline & The Trends - Travel & www.thetrends.ro \\
\hline & Aventurescu - blog de aventuri și călătorii & www.aventurescu.ro \\
\hline & Răzvan Pascu - consultant marketing turistic & www.razvanpascu.ro \\
\hline \multirow{4}{*}{ HU } & Travelinna & www.travellina.hu \\
\hline & Backpacker & www.backpacker.hu \\
\hline & Itt se voltam & www.ittsevoltam.hu \\
\hline & Bringával Bárhova & www.bringavalbarhova.hu \\
\hline
\end{tabular}

The second, Hungarian-speaking target group from Hungary may be accessed through travel blogs and agents from Hungary. The most versatile, Transylvania Hungarian target group in situated at the cross-section of the previous two: they have access to both the Hungarian and the Transylvania Hungarian sources as well as the Romanian travel agencies and blogs from Romania. For the selection of tourist agents in Hungary and Romania we took into account two aspects: on one hand, we selected tourist offices which had the best visibility on Google search results (first 2 results pages), and on the other hand, those tourist offices which have Transylvania as a tourist destination in their offer. 
Table 12. Romanian and Hungarian travel agencies

\begin{tabular}{|c|c|c|}
\hline Country & Travel Agencies & Website \\
\hline \multirow{6}{*}{ RO } & Eximtur & www.eximtur.ro \\
\hline & Karpaten Turism & www.karpaten.ro \\
\hline & Trip\&Tour & www.trip-tour.ro \\
\hline & Mega Travel & www.mega-travel.ro \\
\hline & Via Transylvania Tours & www.viatransylvania.com \\
\hline & Adventure Transylvania & www.adventuretransylvania.com \\
\hline \multirow{12}{*}{ HU } & "Hurrá-Nyaralunk" Travel Agency & www.hurra-nyaralunk.hu \\
\hline & Utazom.com Travel Agency \& Magazine & www.utazom.com \\
\hline & "Start" Travel Agency & www.startutazas.hu \\
\hline & "Vista" Travel Agency & www.vista.hu \\
\hline & "Budavár Tours" Travel Agency & www.budavartours.hu \\
\hline & "Neckermann" Travel Agency & www.neckermann.hu \\
\hline & "Vivaldi Travel" Travel Agency & www.vivalditravel.hu \\
\hline & "Ken-Edi Travel" Travel Agency & www.keneditravel.com \\
\hline & "Proko Travel" Travel Agency & www.prokotravel.hu \\
\hline & "Beki Tours" Travel Agency & www.bekitours.hu \\
\hline & "Kárpáteurópa" Travel Agency & www.karpateuropa.hu \\
\hline & "Csillagösvény" Travel Agency & www.csillagosveny.utazas.hu \\
\hline
\end{tabular}

Travel portals and specialized tour operators (e.g. religious tours, bicycle or motorbike tours, school or community organizers) play an important role in tourism promotion. Every online channel aims to create a partnership, firstly for the proposal of tourist routes, and secondly for a mutual promotion or cross-promotion on online surfaces.

In the second, sustenance phase, besides partnerships the paid advertising means the promotion of the website and Facebook page, Google Ads, FB ads and online advertising. The role of the promoted platforms is to draw attention to activities, new and inbound tours, competitions and events.

Events taking place on the heritage route (conferences, school competitions, camps, promotional online movies, radio and television programs) may be included into the maintenance phase and aftermath of the project. A third promotion phase can also be planned if the project opens a new chapter and is completed with new settlements or if it is extended beyond Transylvania and Hungary, to places that have elements linked to the heritage of St. Ladislaus.

\section{Schedule}

The purpose of the general media or promotion schedule is to systematize and visualize the sequence of events and their connections. Promotion stages include activities of a different purpose, type and asset use that reinforce each other (tonic 
or boosting effect) in order to reach a higher frequency in target groups, thus increasing awareness and positive affinity.

Table 14. The general promotion-plan of the St. Ladislaus Heritage Route, 2017, monthly segmentation

\begin{tabular}{|c|c|c|c|c|c|c|c|c|c|c|c|c|}
\hline 2017 & 01 & 02 & 03 & 04 & 05 & 06 & 07 & 08 & 09 & 10 & 11 & 12 \\
\hline \multicolumn{13}{|l|}{ Own website } \\
\hline \multicolumn{13}{|l|}{ Own social media site } \\
\hline \multicolumn{13}{|l|}{ Visual identity } \\
\hline \multicolumn{13}{|l|}{ Teasing-presentations } \\
\hline \multicolumn{13}{|l|}{ Project reviews } \\
\hline \multicolumn{13}{|l|}{ Mediabuying } \\
\hline \multicolumn{13}{|l|}{ Partner media } \\
\hline \multicolumn{13}{|l|}{ Payed media } \\
\hline \multicolumn{13}{|l|}{ Event-presence } \\
\hline Media appearances & & & & & & & & & & & & \\
\hline
\end{tabular}

Each individual promotional activity may be divided into smaller, more detailed phases, e.g. the frequency of posts in the partner or paid media, or content updates and posts on personal online platforms. The activity of the personal platforms may be further divided and turned into time-bound sections.

Table 15. The St. Ladislaus's Heritage Route's Facebook page schedule

\begin{tabular}{|c|c|c|}
\hline Content type & Displaying & Time \\
\hline $\begin{array}{l}\text { Presentation of the settlement } \\
\text { (own content) }\end{array}$ & picture + short description + link & $\begin{array}{l}1 \text { times a week } \\
\text { (Tuesday } 13-14 \text { or between 18-19) }\end{array}$ \\
\hline $\begin{array}{l}\text { St. Ladislaus legends, fun facts } \\
\text { (own content) }\end{array}$ & $\begin{array}{l}\text { picture }+ \text { short description } \\
\text { formulating questions }\end{array}$ & $\begin{array}{l}1 \text { times a week } \\
\text { (Thursday between 13-14) }\end{array}$ \\
\hline $\begin{array}{l}\text { Media appearances, } \\
\text { project-related news }\end{array}$ & $\begin{array}{l}\text { picture }+ \text { short note, quote }+ \text { link } \\
\text { (source material) }\end{array}$ & $\begin{array}{l}\text { Monday between } 15-16 \text { frequency } \\
\text { depending on relevant content }\end{array}$ \\
\hline $\begin{array}{l}\text { Participation at events } \\
\text { (own content) }\end{array}$ & pictorial report + short description & $\begin{array}{l}\text { Wednesday between } 13-16 \text { frequency } \\
\text { depending on relevant content }\end{array}$ \\
\hline $\begin{array}{l}\text { Accommodation } \\
\text { reviews/ recommendations }\end{array}$ & $\begin{array}{l}\text { picture }+ \text { link (own website where } \\
\text { booking is possible) }\end{array}$ & $\begin{array}{l}1 \text { times every two weeks } \\
\text { (Friday between 13-16) }\end{array}$ \\
\hline Offers from partner travel agencies & $\begin{array}{l}\text { picture }+ \text { short note }+ \text { link } \\
\text { (partner website) }\end{array}$ & $\begin{array}{l}1 \text { times every two weeks } \\
\text { (Saturday-Sunday between 13-16) }\end{array}$ \\
\hline $\begin{array}{l}\text { Travel bloggers' experience reports } \\
\text { and visitor feedback }\end{array}$ & $\begin{array}{l}\text { picture }+ \text { short summary + link } \\
\text { (external blog) }\end{array}$ & $\begin{array}{l}\text { Saturday-Sunday between } 16-19 \text {. fre- } \\
\text { quency depending on relevant content }\end{array}$ \\
\hline
\end{tabular}

The suggested frequency and dates are only indicative. In order to achieve the proposed aims we recommend a regular, pre-scheduled communication to avoid the inactivity of the site for longer periods of time. The minimum intensity consists of three posts a week on the site, one of which should be an entry on a settlement, one an entry related to St. Laszlo, and one entry on a different theme, depending on the relevant content. In addition, for a greater visibility of the Facebook page it 
is recommended to plan at least one $\mathrm{Fb}$ ad campaign on a monthly basis in which we shall formulate campaign messages for different target audiences.

\section{Suggested programs, integrated implementation}

The aim of the heritage route is to link the settlements connected with the St. Ladislaus cult, linking small regions with each other, to strengthen the cult of St. Ladislaus and the promotion of tourism, to enhance the visibility and the visits to the region. In order to achieve this the communication plan of the project searches for opportunities based on cooperation and mutual support for the promotion of the heritage route and the St. Ladislaus cult. It searches for networks, events and channels which can be incorporated into the promotion plan but they function as a subproject or a separate coordination.

1. Creating new pilgrimage routes with the involvement of the settlements situated on the heritage route. Pilgrimages in the Transylvanian lands, especially the celebration of the Pentecost in Șumuleu became an emblematic event. Beside them there are a series of less known events, foreign pilgrimages which involve especially the Roman Catholic Hungarians but, as in the Pentecostal celebration of Șumuleu, they may also develop to become a general, primarily cultural event. Some sections of the St. Ladislaus Heritage Route may be highlighted based on the legends and deeds of the knight-king and turned into a route for pedestrians, cyclists or groups traveling by organized transport means.

2. Proposal for touristic routes. The website may offer a few already available tourist programs. In addition to the elements of the heritage of St. Ladislaus it may offer alternative activities and recreational opportunities, hiking, visiting places and institutions and opportunities for using tourist services. It may calculate distances and suggest dining and accommodation options.

3. Connect with festival and event tourism. Festival and event tourism is becoming more and more intense in Transylvania, and this content is linked to local communities, culture and particularities (e.g. city days) or it is thematic (e.g. music festivals, sport events). Some of these involve tens of thousands of individuals. Visits may be included into the programs or offers, thus visitors could spend a longer time visiting or hiking along the heritage route. The St. Ladislaus Heritage Route may be featured as a historical route that can be followed by visitors or could be connected to other events the participants of which are interested in the historical and cultural heritage, participants who would be willing to travel and become acquainted with the values of their historical heritage.

4. Connect with existing touristic programs and networks. In Transylvania and Hungary as well as in the areas inhabited by the other target groups there are several tourism networks which, along the region in question promote other regions and programs and, based on their previous network project experiences, 
are able to provide a broad representation. These may be specific tourist offices (e.g. specialized in religious tourism, cycling or motorcycle tours, family programs, school programs, etc.) which include into their offer the route in its full length or only certain parts of it. The heritage route may be included into the country image of Romania and Hungary as well as into the related touristic proposals, with a concrete offer for the heritage path.

5. Connect with the media. Media coverage can be achieved primarily by the presence at events as well as by the channels of preferential social ads. The main channels may be those of the public media in Romania and Hungary, the Hungarian language channels of the public and community media in Transylvania as well as the online portals. In addition to the public media the co-operation with a selected commercial media can be bi-directional: it provides visibility to the project and, through program-like appearances, settlement descriptions, casual reports, on-the-spot reports offers material for the media product as well. An own series of radio or television programs or site-based appearances may also provide co-branding by mutual promotion and the shared use of image elements.

6. Media and Event Convergence. The strength of the project lies in the strongest channels of today's mass media: the own interactive site, a social media site and cellphone-based application included in plans. These are the main subjects of promotion, they are the ones appearing in online links, partnerships or purchased surfaces. The content displayed on interactive interface targets an emotional reaction, it presents a powerful visual impact while the interactive map and story creation brings the places and the historical figure of St. Ladislaus closer to the viewer. It includes contact details, accommodation and travel opportunities and the contact details of partners. The newsletters and phone applications are constantly focusing the attention on the visibility and inclusion of new settlements and sites, and a personalized route man be edited depending on the interest of the visitor, the themes, distance and costs. Occasional offers, events, actions, and calls of local institutions may also be accessed directly by users who are potential and recurring visitors of the heritage trail. The project can be further expanded with a tourist card and bonus system, and can be included into the offer of other systems. The project is thus open and prone to be linked with events organized along the heritage trail.

7. Inclusion of the community, crowdsourcing. The project data and descriptions are an open source for other users and programs but, at the same time, the aim is to involve the community into the improvement of the existing data. They may suggest new settlements for historical presentation and visual documentation, additional highlights and events. The link with the community provides a long-term opportunity for mobilization, whether it is a common affair, event or 
fundraising to sustain the project or acquiring self-funding for future applications. The need for completeness is difficult to accomplish but community contribution may bring more accurate data and a better visibility.

\section{References}

1. Benedek, István (2017a). A Szent László örökségút helyzetfelmérése. Korunk, V. folyam, 2017/11 (forthcoming).

2. Benedek, István (2017b). Media and Online Analysis of Settlements from Saint Ladislaus Memorial Road. Journal of Media Research, 10, 2(28), 129-145. Online: www.mrjournal.ro/docs/R2/28JMR9-1.pdf.

3. Covasnamedia (2016). 11 bloggeri în vacanță în județul Covasna. https://covasnamedia.ro/actualitate/11-bloggeri-in-vacanta-in-judetul-covasna, accessed on 15.07.2017

4. Kádár, Magor E. (2017). Szent László király útja. Egy kulturális értékszemle adatgyűjtési és dokumentálási munkálatai. Korunk, V. folyam, 2017/11 (forthcoming).

5. Kádár, Magor E. (2008). Kampánykommunikáció. Kézikönyv a kommunikációs kampányok tervezéséhez és elemzéséhez. Cluj-Napoca: Kriterion.

6. Kádár, Magor E. (2016). Media Image Analysis of the Western Region of Sălaj County. Journal of Media Research, 2016, 9, 3(26), 78-95. Retrieved from www.mr journal.ro/docs/R2/26MR0.pdf. Accessed on 25.04.2017.

7. Kádár, Magor E. (2014). The process of Settlement Branding. Case studies on City Branding in Transylvania. Transylvanian Review of Administrative Sciences. Special Issue, 55-69. Retrieved from http://rtsa.ro/tras/index.php/tras/article/view/413. Accessed on 25.04.2017.

8. Statista (2017). Worldwide desktop market share of leading search engines. Retrieved from www.statista.com/statistics/216573/worldwide-market-share-of-sear ch-engines. Accessed on 25.04.2017.

9. Van Deursen, A.-Van Dijk, J. 2009. Using the Internet: Skill related problems in users online behavior. Interact Comput, 21(5-6), 393-402.

10. WeRadio (2017). Atracțiile turistice din județul Covasna, prezentate în presa centrală. Retrieved from http://weradio.ro/atractiile-turistice-din-judetul-covasnaprezentate-presa-centrala/. Accessed on 15.07.2017. 